\title{
LDLR Gene Polymorphisms (rs5925 and rs1529729) Are Associated with Susceptibility to Coronary Artery Disease in a South Indian Population
}

\author{
Chandan K. Jha ${ }^{1}{ }^{\mathbb{D}}$, Rashid Mir ${ }^{2}{ }^{\mathbb{D}}$, Imadeldin Elfaki ${ }^{3}$, Shaheena Banu ${ }^{4}$ and S. M. S. Chahal ${ }^{1, *}$ \\ 1 Department of Human Genetics, Punjabi University, Punjab 147002, India \\ 2 Department of Medical Lab Technology, Faculty of Applied Medical Sciences, University of Tabuk, Tabuk \\ 71491, Saudi Arabia \\ 3 Department of Biochemistry, Faculty of Science, University of Tabuk, Tabuk 71491, Saudi Arabia \\ 4 Sri Jayadeva Institute of Cardiovascular Science and Research, Bangalore 560069, India \\ * Correspondence: smschahal1@gmail.com
}

Received: 9 June 2019; Accepted: 8 July 2019; Published: 15 July 2019

\begin{abstract}
Cardiovascular diseases (CVD) are a major cause of death in India and worldwide. Atherosclerosis is caused by the interaction of environmental and genetic factors. Hypercholesterolemia is an example of a classical risk factor for CVD. The low-density lipoprotein receptor (LDLR) is one of the regulating mechanisms the liver uses for cholesterol homeostasis. Gene variations in the LDLR have been reported to cause hypercholesterolemia and consequently CVD. We investigated the association of polymorphisms in the LDLR (rs5925 and rs1529729) with coronary artery disease (CAD) in 200 coronary artery disease patients and 200 matched healthy controls using allele-specific PCR (AS-PCR). The results indicated that the CT genotype of the rs1529729 polymorphism was associated a decreased susceptibility to CAD with an odds ratio (OR) $=0.42(95 \%$ confidence interval $(\mathrm{CI}), 0.23-0.77)$, risk ratio $(\mathrm{RR})=0.59(0.39-0.89), P=0.0047$. The TT genotype of the rs1529729 polymorphism was also associated with decreased susceptibility to CAD with an $\mathrm{OR}=0.19(95 \% \mathrm{CI}, 0.076-0.47), \mathrm{RR}=0.57(0.47-0.69), P=0.0003$. The GA genotype of the rs5925 polymorphism was associated with decreased susceptibility to CAD with an OR $=0.45$ (95\% CI, $0.27-0.75), \mathrm{RR}=0.65(0.47-0.88), P=0.002$. We concluded that the CT and TT genotypes of the rs1529729 polymorphism and the GA genotype of the rs5925 polymorphism are probably associated with decreased susceptibility to CAD. The simplicity of AS-PCR makes it particularly suitable for the rapid, large-scale screening of gene variabilities in the LDLR. AS-PCR could provide significant benefits in clinical applications with its ability to amplify a lower quantity of samples in a cost-saving manner. Nevertheless, these findings need to be validated in well-designed studies with larger sample sizes and in different populations.
\end{abstract}

Keywords: cardiovascular diseases (CVD); allele-specific-PCR; lipoprotein receptor (LDLR); atherosclerosis; SNPs rs5925 and rs1529729; hypercholesterolemia

\section{Introduction}

Coronary artery disease (CAD) is a complex disease resulting from the interaction of genetic and environmental factors. Traditional risk factors for atherosclerosis include obesity, hypercholesterolemia, smoking, hypertension, and hyperglycemia [1]. These factors lead to an excessive accumulation of cholesterol, which results in hardening of and accumulation of thrombotic debris in the artery wall [2]. The steps involved in the formation of an atherosclerotic lesion begin with an injury to the endothelial wall, after which the retention of lipid particles occurs, followed by inflammation. These steps lead to the generation of a necrotic core (containing cell debris and lipids) covered by a fibrous cap, eventually 
leading to the formation of an atheromatous plaque [3]. Hypercholesterolemia is one of the important risk factors involved in the formation of atherosclerotic plaques [4]. It has been reported that the deposition of cholesterol particles in the endothelial wall initiates the inflammatory response, which involves the activation of macrophages and lymphocytes, as well as the production of cytokines (including tumor necrosis factor-alpha, interleukin-6, and interferon-gamma) [5], and enhances the development of atheroma [4]. Cholesterol is pooled in the liver from the diet or from cholesterol that is synthesized by cells. The liver is the primary organ for the regulation of cholesterol homeostasis, and the low-density lipoprotein receptor (LDLR) is one of the regulating mechanisms [6]. The LDLR is a transmembrane glycoprotein that plays an important role in the uptake of low-density lipoprotein (LDL) from the blood circulation in a process that is mediated by apolipoprotein B $[7,8]$. The LDLR binds at neutral $\mathrm{pH}$ specifically and with a high affinity to extracellular lipoprotein particles [9]. The LDLR and LDL-cholesterol complex is then brought into the cell by endocytosis [10]. LDL-cholesterol is then released by the LDLR at an acidic $\mathrm{pH}$ for degradation by a lysosome which results in the release of free cholesterol and the return of the LDLR to the cell surface [9]. Genome-wide association studies (GWASs) have discovered certain novel gene loci that reproducibly associate with diseases [11-13], including CAD [14-20] and atherosclerosis [21,22]. Mutations in the LDLR gene have been reported to cause familial hypercholesterolemia [18,23]. In the present study, we investigated the association of polymorphisms in the LDLR (rs5925 and rs1529729) and CAD in a cohort from the Bangalore population.

\section{Subjects and Methods}

This project has been approved by the institutional ethics committee (IEC), Punjabi University, Patiala, project No. 268/DLS/HG. We conducted a population-based case-control study including 200 patients with clinically confirmed CAD and 200 healthy controls (HC) with no history of CAD and no familial relationship to the CAD patients. We excluded any patient with a previous history of chronic disease from this study.

\subsection{Collection of Blood Samples and Clinical History}

About $3 \mathrm{~mL}$ of peripheral blood was collected in an EDTA-containing vial from each patient and healthy control after they completed a questionnaire. We collected information as well as an informed written consent form from both CAD patients and healthy controls regarding personal information such as name, gender, and age. Additionally, information regarding a history of sexually transmitted diseases and addiction, such as smoking and alcohol, were collected. We also collected laboratory and clinical data.

\subsection{Extraction of $D N A$}

DNA was extracted from the blood using the modified glass bead method, as described in a previous study [24]. The extracted DNA was dissolved in $100 \mu \mathrm{L}$ of $10 \mathrm{mM}$ Tris- $\mathrm{Cl}$ (pH 8.0) buffer and stored at $4{ }^{\circ} \mathrm{C}$ until use. The quality of the DNA was assessed by gel electrophoresis.

\subsection{Genotyping of the LDLR Polymorphisms (rs5925 and rs1529729)}

Gene polymorphisms were detected using allele-specific PCR (AS-PCR). AS-PCR is based on the use of sequence-specific PCR primers that allow for amplification of the template DNA when the target allele is contained within the sample. Primers were designed using primer 3 software (Table 1, Figure 1). For rs5925, AS-PCR was performed in two tubes with each of the tubes containing a common forward primer and a different reverse primer. The reaction mixtures for the rs5925 AS-PCR contained template DNA, $3-4 \mu \mathrm{L}$ (50 ng); the common forward primer, $0.3 \mu \mathrm{L}$ ( 25 pmol); a reverse primer, $0.3 \mu \mathrm{L}(25 \mathrm{pmol})$; Coral load dye, $2.5 \mu \mathrm{L} ; 12.5 \mu \mathrm{L}$ of TopTaq Master Mix (Qiagen, Germany); and enough nuclease free $\mathrm{ddH}_{2} \mathrm{O}$ to bring the final volume to $25 \mu \mathrm{L}$. The AS-PCR for rs1529729 was performed in two tubes, each containing a different primer set. The reaction mixture for the rs152972 AS-PCR contained DNA template, $3-4 \mu \mathrm{L}$ (50 ng); either the F1/R2 or the F2/R1 primer combinations, $0.3 \mu \mathrm{L}$ of each primer 
(25 pmol); Coral load dye, 2.5 $\mu \mathrm{L} ; 12.5 \mu \mathrm{L}$ of TopTaq Master Mix (Qiagen, Germany); and enough nuclease free $\mathrm{ddH}_{2} \mathrm{O}$ to bring the final volume to $25 \mu \mathrm{L}$. The PCR conditions used were as follows: initial denaturation for $10 \mathrm{~min}$ at $95^{\circ} \mathrm{C}, 35$ cycles of $30 \mathrm{~s}$ at $95^{\circ} \mathrm{C}$ (denaturation), $30 \mathrm{~s}$ at $57^{\circ} \mathrm{C}$ (the rs5925 AS-PCR) or $61^{\circ} \mathrm{C}$ (the rs1529729 AS-PCR) (annealing), and $1 \mathrm{~min}$ at $72{ }^{\circ} \mathrm{C}$ (elongation), followed by $10 \mathrm{~min}$ at $72{ }^{\circ} \mathrm{C}$ (final elongation). The PCR products were visualized using electrophoresis via $2 \%$ agarose gel stained with ethidium bromide (Figure 2). The lengths of the PCR products for rs1529729 were $212 \mathrm{bp}$ for F1/R1, and $175 \mathrm{bp}$ for F2/R2 PCR products, and $176 \mathrm{bp}$ for the rs5925 (Figure 2).

\section{A}

rs1529729

$\begin{array}{r}\text { F2 } \\ \hline \text { F1 }\end{array}$

GTGGTGCCATGTATAACACCC/TTTTGTCACAGTGCTCTCATTTCGTCGTGTAAAAGGCCAGTCCCCGCCTCGCAGT GTTGGGGCAGCCAGCACAGGCACGTGAGACAGGAGCCACACCTGGGTTCTCATCTGGCATCTGCCTCTTGCCATGC TCAGGTTCTTGCCTCCAGATATAGGGCATCAAACTAAGTGGTTTCCAAACTTGGGTTCTTG

B

R2 R1

rs5925

Common Forward primer

CAGTGTTIAACGGGATTTGTCATCTTCCTTGCTGCCTGTTTAGGACAAAGTATTTTGGACAGATATCATCAACGAAG CCATITICAGTGCCAACCGCCTCACAGGTTCCGATGTCAACTTGTTGGCTGAAAACCTACTGTCCCCAGAGGATATG GTC/TCTCTTCCACAACCTCACCC

Reverse primers

Figure 1. The annealing sites of the primers used for genotyping rs1529729 (A) and rs5925 (B).

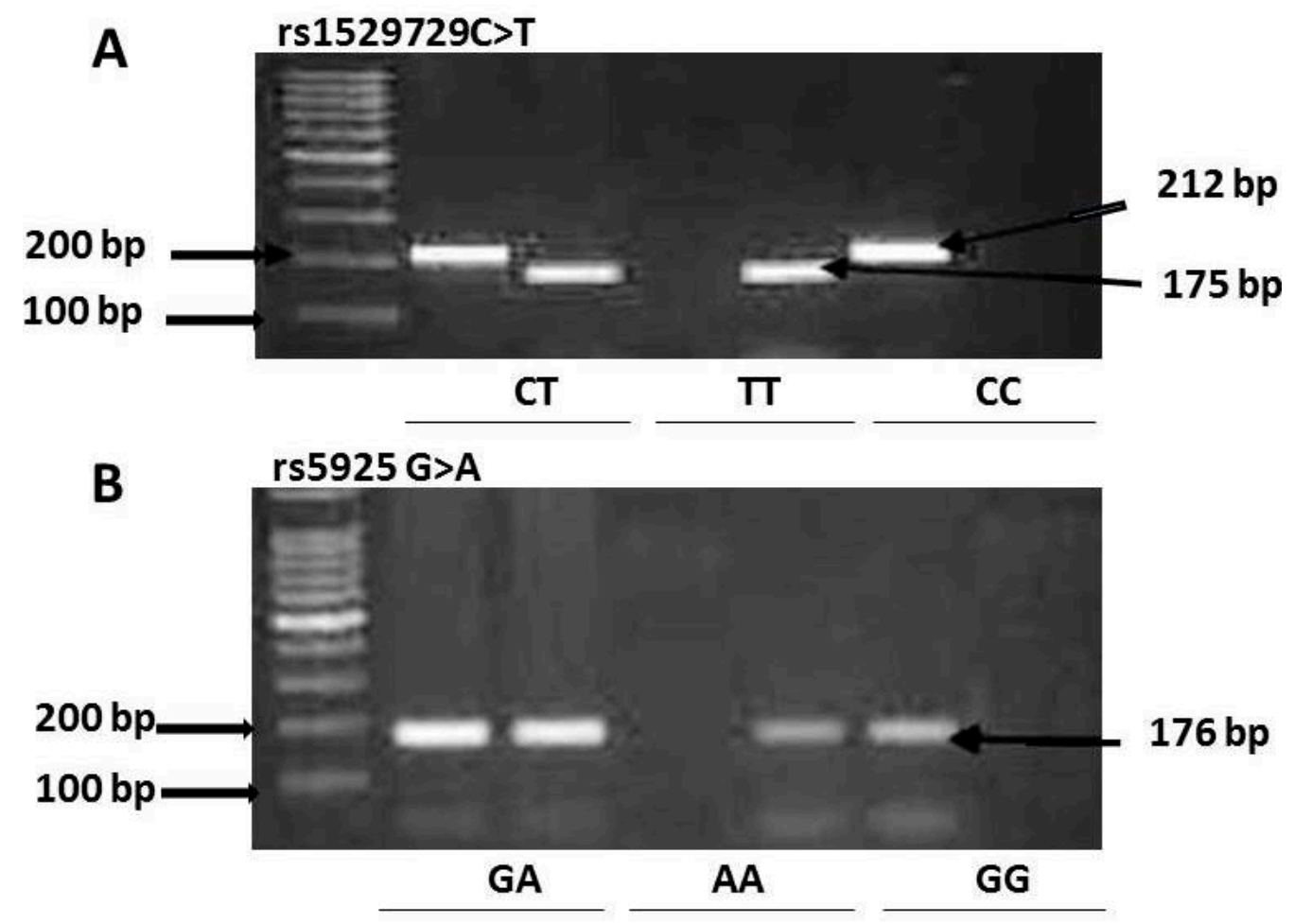

Figure 2. Genotyping of rs1529729 C > T (A) and rs5925 G > A (B) polymorphisms using allele-specific PCR (AS-PCR) assay. 


\subsection{Statistical Analysis}

Group differences were compared using a Student's two-sample $t$-test or a one-way analysis of variance (ANOVA) for continuous variables, and a Chi-square test for categorical variables. Differences in both the single nucleotide polymorphism SNP allele and in the genotype frequencies between groups were evaluated using the Chi-square test. The associations between both SNP genotypes and the risk of CAD were estimated by computing the odds ratios (ORs), risk ratios (RRs), and risk differences (RDs) with 95\% confidence intervals (CIs). Allele frequencies among cases, as well as controls, were evaluated using the Chi-square test. $P<0.05$ was considered significant. All statistical analyses were performed using SPSS 16.0 (IBM, Chicago, IL, USA).

\section{Results}

A total of 200 CAD patients and 200 healthy controls were included in this study. The demographic characteristics of CAD patients and controls are shown in Table 2. The ratios of gender and age differences in CAD patients are comparable to those of the control group. The clinical characteristics of the CAD patients are shown in Table 3.

Table 1. Primers sequences of allele-specific (AS)-PCR used for genotyping the low-density lipoprotein receptor (LDLR) gene polymorphisms rs1529729 and rs5925.

\begin{tabular}{|c|c|c|c|c|}
\hline SNP & & Primer Sequence & Product Size & $\mathbf{T}_{\mathbf{a}}$ \\
\hline \multirow{4}{*}{ rs1529729 } & F1 Forward primer (C allele) & 5-GTGGTGCCATGTATAACACCC-3 & $175 \mathrm{bp}$ & \multirow{4}{*}{$61^{\circ} \mathrm{C}$} \\
\hline & R1 Reverse primer & 5-CAAGAACCCAAGTTTGGAAAC-3 & & \\
\hline & F2 Forward primer ( $\mathrm{T}$ allele) & 5-GTGGTGCCATGTATAACACCT-3 & 212 bp & \\
\hline & R2 Reverse primer & 5-CTATATCTGGAGGCAAGAACCTGA-3 & & \\
\hline \multirow{3}{*}{ rs5925 } & Reverse primer (G allele) & 5'-GGGTGAGGTTGTGGAAGACG-3' & $176 \mathrm{bp}$ & \multirow{3}{*}{$57^{\circ} \mathrm{C}$} \\
\hline & Reverse primer (A allele) & 5'-GGGTGAGGTTGTGGAAGACA-3' & $176 \mathrm{bp}$ & \\
\hline & Common Forward primer & 5'-CAGTGTTTAACGGGATTTGT-3' & & \\
\hline
\end{tabular}

Table 2. Demographic characteristics of coronary artery disease (CAD) patients and healthy controls.

\begin{tabular}{ccc}
\hline Variables & $\begin{array}{c}\text { No. of CAD Cases } \\
(\boldsymbol{n}=\mathbf{2 0 0}(\mathbf{1 0 0} \%)\end{array}$ & $\begin{array}{c}\text { No. of Healthy Controls } \\
(\boldsymbol{n}=\mathbf{2 0 0}(\mathbf{1 0 0})\end{array}$ \\
\hline No. of cases and controls & $200(100 \%)$ & $200(100 \%)$ \\
\hline Males & $180(90 \%)$ & $176(88 \%)$ \\
\hline Females & $20(10 \%)$ & $24(12 \%)$ \\
\hline Age $\leq 50$ & Age difference & $88(44 \%)$ \\
\hline Age $>50$ & $90(45 \%)$ & $112(56 \%)$ \\
\hline
\end{tabular}

\subsection{The Genotype Frequency of the LDLR Polymorphisms rs1529729 and rs5925}

The genotype frequency of the rs1529729 polymorphisms CC, CT, TT in patients were 9, 77, and $14 \%$, respectively, whereas they were 21,76 , and $3 \%$ in controls, respectively. The differences in the proportions of the genotype frequencies were significantly different $(P=0.0001$, Table 4$)$. The genotype frequency of the rs5925 polymorphisms GG, GA, AA in patients were 27, 62, and $11 \%$ respectively, whereas they were 15,76 , and $9 \%$ in controls, respectively. The differences in the proportions of the genotype frequencies were significantly different $(P=0.006$, Table 4$)$. 
Table 3. Baseline characteristics of CAD patients.

\begin{tabular}{|c|c|c|}
\hline Variables & CAD Cases $(n=200)$ & $(\%)$ \\
\hline \multicolumn{3}{|c|}{ Random blood sugar (RBS) } \\
\hline$\leq 140 \mathrm{mg}$ & 129 & $(64.5 \%)$ \\
\hline$>140 \mathrm{mg}$ & 71 & $(35.5 \%)$ \\
\hline \multicolumn{3}{|c|}{ Cholesterol } \\
\hline$\leq 200 \mathrm{mg}$ & 176 & $(88 \%)$ \\
\hline$>200 \mathrm{mg}$ & 24 & $(12 \%)$ \\
\hline \multicolumn{3}{|c|}{ High-density lipoprotein cholesterol (HDL-C) } \\
\hline$\leq 40 \mathrm{mg}$ & 166 & $(83 \%)$ \\
\hline$>40 \mathrm{mg}$ & 34 & $(17 \%)$ \\
\hline \multicolumn{3}{|c|}{ Low-density lipoprotein cholesterol (LDL-C) } \\
\hline$\leq 100 \mathrm{mg}$ & 150 & $(75 \%)$ \\
\hline$>100 \mathrm{mg}$ & 50 & $(25 \%)$ \\
\hline \multicolumn{3}{|c|}{ Triglycerides (TGL) } \\
\hline$\leq 150 \mathrm{mg}$ & 105 & $(52.5 \%)$ \\
\hline$>150 \mathrm{mg}$ & 95 & $(47.5 \%)$ \\
\hline \multicolumn{3}{|c|}{ Coronary heart disease (CHD) in family } \\
\hline Yes & 15 & $(7.5 \%)$ \\
\hline No & 185 & $(92.5 \%)$ \\
\hline \multicolumn{3}{|c|}{ Hypertension } \\
\hline Yes & 29 & $(14.5 \%)$ \\
\hline No & 171 & $(85.5 \%)$ \\
\hline \multicolumn{3}{|c|}{ Type 2 diabetes } \\
\hline Yes & 39 & $(19.5 \%)$ \\
\hline No & 161 & $(80.5 \%)$ \\
\hline \multicolumn{3}{|c|}{ Smoking } \\
\hline Yes & 121 & $(60.5 \%)$ \\
\hline No & 79 & $(39.5 \%)$ \\
\hline \multicolumn{3}{|c|}{ Alcohol } \\
\hline Yes & 71 & $(35.5 \%)$ \\
\hline No & 129 & $(64.5 \%)$ \\
\hline \multicolumn{3}{|c|}{ Pan masala } \\
\hline Yes & 4 & $(2 \%)$ \\
\hline No & 196 & $(98 \%)$ \\
\hline
\end{tabular}

Table 4. The genotype frequency of the LDLR polymorphisms of study cohorts (controls and CAD patients).

\begin{tabular}{cccccccc}
\hline SNP & Genotype & C/C & C/T & T/T & Chi-Square & Df & $P$-Value \\
\hline \multirow{2}{*}{ rs1529729 } & CAD patients $n=200(\%)$ & $18(9 \%)$ & $154(77 \%)$ & $28(14 \%)$ & 23.85 & 2 & 0.0001 \\
\cline { 2 - 8 } & Controls $n=200(\%)$ & $42(21 \%)$ & $152(76 \%)$ & $06(3 \%)$ & & & \\
\hline \multirow{2}{*}{ rs5925 } & Genotype & G/G & G/A & A/A & Chi-square & Df & $P$-value \\
\cline { 2 - 8 } & CAD patients $n=200(\%)$ & $54(27 \%)$ & $124(62 \%)$ & $22(11 \%)$ & 10.1 & 2 & 0.006 \\
\cline { 2 - 8 } & Controls $n=200(\%)$ & $30(15 \%)$ & $152(76 \%)$ & $18(9 \%)$ & & & \\
\hline
\end{tabular}




\section{2. rs1529729 C > T and rs5925 G > A Polymorphisms Were Associated with CAD}

The results of the present study indicated that in the codominant model the CT genotype of the rs1529729 polymorphism was associated with a decreased susceptibility to CAD with an OR $=0.42$ (95\% CI, 0.23-0.77), RR $=0.59(0.39-0.89), P=0.0047$. The TT genotype was also associated with a reduced risk for $\mathrm{CAD}$ with an $\mathrm{OR}=0.09(95 \% \mathrm{CI}, 0.03-0.26), \mathrm{RR}=0.36(0.24-0.55), P=0.0001$ (Table 5). In the dominant model the $\mathrm{CT}+\mathrm{TT}$ genotype was associated with a decreased susceptibility to CAD with an $\mathrm{OR}=0.37(95 \% \mathrm{CI}, 0.21-0.67), \mathrm{RR}=0.56(0.38-0.84), P=0.001$. The TT genotype was associated with decreased susceptibility to CAD with $\mathrm{OR}=0.19(95 \% \mathrm{CI}, 0.076-0.47), \mathrm{RR}=0.57(0.47-0.69)$, $P=0.0003$ (Table 5).

Table 5. Association of the $L D L R$ rs1529729 C > T and rs5925 G > A gene variations with CAD.

\begin{tabular}{|c|c|c|c|c|c|c|}
\hline SNP & Genotypes & $\begin{array}{l}\text { Healthy } \\
\text { Controls }\end{array}$ & CAD Cases & $\begin{array}{c}\text { Odds Ratio (OR) } \\
(95 \% \mathrm{CI})\end{array}$ & Risk Ratio (RR) & $P$-Value \\
\hline \multirow{14}{*}{ rs1529729 } & & $(n=200)$ & $(n=200)$ & & & \\
\hline & Codominant & & & & & \\
\hline & LDLR-CC & 42 & 18 & 1 (ref.) & 1 (ref.) & \\
\hline & LDLR-CT & 152 & 154 & $0.42(0.23-0.77)$ & $0.59(0.39-0.89)$ & 0.0047 \\
\hline & LDLR-TT & 06 & 28 & $0.09(0.03-0.26)$ & $0.36(0.24-0.55)$ & 0.0001 \\
\hline & Dominant & & & & & \\
\hline & LDLR-CC & 42 & 18 & 1 (ref.) & 1 (ref.) & \\
\hline & LDLR-(CT + TT) & 158 & 182 & $0.37(0.21-0.67)$ & $0.56(0.38-0.84)$ & 0.001 \\
\hline & Recessive & & & & & \\
\hline & $\begin{array}{l}\text { LDLR-(CC + } \\
\text { CT) }\end{array}$ & 194 & 172 & 1 (ref.) & 1 (ref.) & \\
\hline & LDLR-TT & 06 & 28 & $0.19(0.076-0.47)$ & $0.57(0.47-0.69)$ & 0.0003 \\
\hline & Allele & & & & & \\
\hline & LDLR-C & 236 & 190 & 1 (ref.) & 1 (ref.) & \\
\hline & LDLR-T & 164 & 210 & $0.63(0.47-0.83)$ & $0.79(0.69-0.91)$ & 0.0011 \\
\hline \multirow{13}{*}{ rs5925 } & Codominant & & & & & \\
\hline & LDLR-GG & 30 & 54 & 1 (ref.) & 1 (ref.) & \\
\hline & LDLR-GA & 152 & 124 & $0.45(0.27-0.75)$ & $0.65(0.47-0.88)$ & 0.002 \\
\hline & LDLR-AA & 18 & 22 & $0.67(0.32-1.46)$ & $0.79(0.50-1.24)$ & 0.322 \\
\hline & Dominant & & & & & \\
\hline & LDLR-GG & 30 & 54 & 1 (ref.) & 1 (ref.) & \\
\hline & LDLR-(GA+AA) & 170 & 146 & $0.477(0.28-0.78)$ & $0.66(0.48-0.9)$ & 0.003 \\
\hline & Recessive & & & & & \\
\hline & LDLR-(GG+GA) & 182 & 178 & 1 (ref.) & 1 (ref.) & \\
\hline & LDLR-AA & 18 & 22 & $1.24(0.64-2.4)$ & $1.12(0.78-1.6)$ & 0.5 \\
\hline & Allele & & & & & \\
\hline & LDLR-G & 212 & 232 & 1 (ref.) & 1 (ref.) & \\
\hline & LDLR-A & 188 & 168 & $0.8(0.61-1.07)$ & $0.9(0.78-1.03)$ & 0.107 \\
\hline
\end{tabular}

Our results also showed that in the codominant model the GA genotype of the rs5925 polymorphism was associated with a decreased susceptibility to CAD, OR $=0.45$ (95\% CI, 0.27-0.75), RR $=0.65$ $(0.47-0.88), P=0.002$. In the dominant model the GA + AA genotype was associated with a reduced risk of CAD with $\mathrm{OR}=0.477(95 \% \mathrm{CI}, 0.28-0.78), \mathrm{RR}=0.66(0.48-0.9), P=0.003$ (Table 5). Our results also showed that covariates such as gender, age, blood levels of random sugar, total cholesterol, low-density lipoprotein cholesterol (LDL-C), and high-density lipoprotein cholesterol (HDL-C) were non-significantly different $(P>0.05)$ among the genotypes of both the SNPs in the patient group. We also did not see significant effects $(P>0.05)$ of diabetes, hypertension, intake of alcohol, smoking, 
and pan masala on either the rs5925 or the rs1529729 polymorphisms (Table 6). These results were unexpected and might be due to the limited sample size used in this research.

Table 6. Correlations of the covariates with rs5925 and rs1529729 genotypes.

\begin{tabular}{|c|c|c|c|c|c|c|c|c|c|c|c|c|c|}
\hline \multicolumn{8}{|c|}{ rs1529729 } & \multicolumn{6}{|c|}{ rs5925 } \\
\hline Subjects & $n=200$ & $\mathrm{C} / \mathrm{C}$ & $\mathrm{C} / \mathrm{T}$ & $\mathrm{T} / \mathrm{T}$ & $x^{2}$ & $\mathrm{DF}$ & $P$ value & G/G & $\mathrm{G} / \mathrm{A}$ & $\mathrm{A} / \mathrm{A}$ & $x^{2}$ & DF & $P$-value \\
\hline \multicolumn{14}{|c|}{ Correlation with gender } \\
\hline Males & 180 & 15 & 138 & 27 & 2.2 & 2 & 0.33 & 48 & 111 & 21 & 0.83 & 2 & 0.66 \\
\hline Females & 20 & 03 & 16 & 01 & & & & 06 & 13 & 01 & & & \\
\hline \multicolumn{14}{|c|}{ Correlation with age } \\
\hline Age $\leq 50$ & 90 & 07 & 73 & 10 & 1.61 & 2 & 0.447 & 23 & 58 & 09 & 0.43 & 2 & 0.806 \\
\hline Age $>50$ & 110 & 11 & 81 & 18 & & & & 31 & 66 & 13 & & & \\
\hline \multicolumn{14}{|c|}{ Correlation with RBS } \\
\hline RBS $\leq 140 \mathrm{mg}$ & 129 & 13 & 98 & 18 & 0.52 & 2 & 0.77 & 33 & 83 & 13 & 0.87 & 2 & 0.647 \\
\hline RBS $>140 \mathrm{mg}$ & 71 & 05 & 56 & 10 & & & & 21 & 41 & 09 & & & \\
\hline \multicolumn{14}{|c|}{ Correlation with cholesterol } \\
\hline Cholesterol $\leq 200 \mathrm{mg}$ & 176 & 14 & 137 & 25 & 1.96 & 2 & 0.375 & 45 & 114 & 17 & 5.33 & 2 & 0.069 \\
\hline Cholesterol > $200 \mathrm{mg}$ & 24 & 04 & 17 & 03 & & & & 09 & 10 & 05 & & & \\
\hline \multicolumn{14}{|c|}{ Correlation with HDL } \\
\hline $\mathrm{HDL} \leq 40 \mathrm{mg}$ & 166 & 14 & 128 & 24 & 0.5 & 2 & 0.778 & 44 & 104 & 18 & 0.18 & 2 & 0.913 \\
\hline $\mathrm{HDL}>40 \mathrm{mg}$ & 34 & 04 & 26 & 04 & & & & 10 & 20 & 04 & & & \\
\hline \multicolumn{14}{|c|}{ Correlation with LDL } \\
\hline $\mathrm{LDL} \leq 100 \mathrm{mg}$ & 150 & 15 & 113 & 22 & 1.07 & 2 & 0.5857 & 44 & 92 & 14 & 2.77 & 2 & 0.25 \\
\hline LDL > $100 \mathrm{mg}$ & 50 & 03 & 41 & 06 & & & & 10 & 32 & 08 & & & \\
\hline \multicolumn{14}{|c|}{ Correlation with TGL } \\
\hline TGL $\leq 150 \mathrm{mg}$ & 105 & 10 & 79 & 16 & 0.4 & 2 & 0.8187 & 25 & 66 & 14 & 1.95 & 2 & 0.377 \\
\hline TGL > $150 \mathrm{mg}$ & 95 & 08 & 75 & 12 & & & & 29 & 58 & 08 & & & \\
\hline \multicolumn{14}{|c|}{ Correlation with hypertension } \\
\hline Hypertension & 29 & 03 & 22 & 04 & 0.07 & 2 & 0.9656 & 04 & 22 & 03 & 3.26 & 2 & 0.195 \\
\hline No hypertension & 171 & 15 & 132 & 24 & & & & 50 & 102 & 19 & & & \\
\hline \multicolumn{14}{|c|}{ Correlation with diabetes } \\
\hline Diabetes & 39 & 04 & 30 & 05 & 0.13 & 2 & 0.9371 & 07 & 28 & 04 & 2.24 & 2 & 0.326 \\
\hline No diabetes & 161 & 14 & 124 & 23 & & & & 47 & 96 & 18 & & & \\
\hline \multicolumn{14}{|c|}{ Correlation with CHD } \\
\hline CHD & 15 & 02 & 11 & 02 & 0.37 & 2 & 0.8311 & 01 & 12 & 02 & 3.41 & 2 & 0.181 \\
\hline No CHD & 185 & 16 & 143 & 26 & & & & 53 & 112 & 20 & & & \\
\hline \multicolumn{14}{|c|}{ Correlation with smoking } \\
\hline Smoking & 121 & 13 & 93 & 15 & 1.6 & 2 & 0.4493 & 26 & 45 & 08 & 2.32 & 2 & 0.313 \\
\hline No smoking & 79 & 05 & 61 & 13 & & & & 28 & 79 & 14 & & & \\
\hline \multicolumn{14}{|c|}{ Correlation with alcohol } \\
\hline Alcohol & 71 & 8 & 52 & 11 & 1.01 & 2 & 0.6035 & 18 & 47 & 06 & 1.07 & 2 & 0.585 \\
\hline No alcohol & 129 & 10 & 102 & 17 & & & & 36 & 77 & 16 & & & \\
\hline \multicolumn{14}{|c|}{ Correlation with pan masala } \\
\hline Pan masala & 04 & 00 & 04 & 00 & 1.22 & 2 & 0.5434 & 00 & 03 & 01 & 1.94 & 2 & 0.379 \\
\hline No pan masala & 196 & 18 & 150 & 28 & & & & 54 & 121 & 21 & & & \\
\hline
\end{tabular}

\section{Discussion}

\subsection{Association of rs1529729 C > T and rs5925 G > A Genotypes with CAD}

Cardiovascular disease (CVD) represents an economic and health burden all over the world [25]. CVD has become a leading cause of death in all parts of India. In India, CVD has increased by 59\%, from 23.2 million (1990) to 37 million (2010) [26]. One thousand and seven hundred mutations in the LDLR gene have been associated with familial hypercholesterolemia [23], which is one of the traditional risk factors for CVD [27]. This fact has prompted us to examine the association of the LDLR 
rs1529729 C > T and rs5925 G > A gene variations with CAD. Our results indicated that the rs1529729 $\mathrm{C}>\mathrm{T}$ genotype distribution is different between the cases and the control $(P$-value $=0.0001$, Table 4$)$. Moreover, our results showed that the CT and TT genotypes of rs1529729 C $>$ T are associated with decreased susceptibility to CAD with an $\mathrm{OR}=0.42$ (95\% CI, 0.23-0.77), RR $=0.59$ (0.39-0.89), $P=$ 0.0047 , and an OR $=0.09$ (95\% CI, 0.03-0.26), RR $=0.36$ (0.24-0.55), $P=0.0001$, respectively (Table 5). At the allelic level, the $\mathrm{T}$ allele is associated with a reduced susceptibility to CAD with an OR $=0.63$ (95\% CI, 0.47-0.83), RR $=0.79$ (0.69-0.91), $P=0.0011$ (Table 5). We did not see significant differences in the random blood sugar (RBS), triglyceride, cholesterol, HDL-C, and LDL-C levels between the rs1529729 genotypes in CAD patients ( $P$-value $>0.05$, Table 6$)$. This may be due to the relatively small sample size taken in this study. These results may be in good agreement with the study by Kathiresan et al., 2008 [28].

The results showed that the rs5925 G > A genotype distribution is different between the cases and the control $(P$-value $=0.006$, Table 4$)$. It was indicated that the GA genotype of the rs5925 polymorphism is associated with decreased susceptibility to CAD with an $\mathrm{OR}=0.45(95 \% \mathrm{CI}, 0.27-0.75), \mathrm{RR}=0.65$ $(0.47-0.88), P=0.002$. The rs5925 polymorphism (in cooperation with the rs688 polymorphism) has been shown to regulate the splicing efficiency of the LDLR gene [29]. This result may be consistent with a study that showed that the rs 5925 polymorphism is associated with the thickness of the carotid-intima media in Slovenian type 2 diabetes T2D patients [30]. Furthermore, the rs5925 polymorphism has been predicted to be one of the SNPs that cause familial hypercholesterolemia in the Malaysian population [31].

Our results also showed that there are no significant differences $(P>0.05)$ between the rs5925 genotype distribution and RBS, triglycerides, cholesterol, HDL-C, and LDL-C levels (Table 6). Again, these results may be due to the small sample size, or perhaps some of the CAD patients had been treated with hypolipidemic agents. LDLR is a transmembrane glycoprotein at the hepatocyte surface that plays an important role in cholesterol homeostasis [8]. We suggest that the T allele of the rs 1529729 polymorphism and the GA genotype of the rs5925 polymorphism protect against CAD by increasing the expression of LDLR at the hepatocyte surface such that LDL-C uptake and metabolism is enhanced. In support of this suggestion, the rs5925 polymorphism has been described as an exon-splicing enhancer [29]. However, the effect of rs1529729 and rs5925 polymorphisms on LDLR expression should be to be elucidated in a future study.

To our knowledge, this is the first study that has shown the potential associations of the rs5925 and rs1529729 polymorphisms with CAD in a South Indian population. The limitations of this study include a relatively small sample size and the fact that the study population contained a high percentage of males compared to females (Table 2).

\subsection{The Frequency of the rs5925 and rs1529729 Polymorphisms in Different Populations}

The frequency of the rs 5925 genotypes GG, GA, and AA has been studied in different populations (Table 7). The frequency of the rs1529729 genotypes CC, CT, and TT have been reported in an Iranian population as $28.43,42.16$, and $29.41 \%$, respectively (Table 7). In the present study, the rs 1529729 genotype distributions were 21,76 , and $3 \%$ (Table 7 ). This difference may be due to the different sample size or different ethnicity.

The results showed that the lowest percentage of the GG genotype in controls was (4\%) in the Taiwanese population, while the highest was (56.5\%) in the Chinese population (Table 7). Our study found that the GG genotype in controls was 15\%, which is consistent with previous findings (Table 7). The GA genotype ranged from 51 to $34 \%$ in Mexican and Taiwanese populations, respectively. The GA genotype in our study was relatively high (76\%). In this study, the AA genotype in the control group was $9 \%$, which is within the range of previous findings ( 8 to $62 \%$ ) in Chinese and Taiwanese populations, respectively (Table 7). 
Table 7. The rs5925 G > A and rs1529729 C > T genotype distributions in different populations.

\begin{tabular}{|c|c|c|c|c|c|c|c|c|c|}
\hline \multicolumn{10}{|l|}{ rs5925 } \\
\hline \multirow{2}{*}{$\begin{array}{l}\text { Country } \\
\text { Mexico }\end{array}$} & \multirow{2}{*}{$\begin{array}{c}\text { Disease } \\
\text { Hypertension }\end{array}$} & \multirow{2}{*}{$\begin{array}{c}n \\
160\end{array}$} & \multirow{2}{*}{$\begin{array}{c}\begin{array}{c}\text { Homozygous } \\
\text { Wild Type }\end{array} \\
36\end{array}$} & \multirow{2}{*}{$\begin{array}{c}\% \\
22.5\end{array}$} & \multicolumn{2}{|c|}{ Heterozygous\% } & \multirow{2}{*}{$\begin{array}{c}\begin{array}{c}\text { Homozygous } \\
\text { Mutant }\end{array} \\
51 \\
\end{array}$} & \multirow{2}{*}{$\begin{array}{c}\% \\
31.87\end{array}$} & \multirow{2}{*}{$\begin{array}{c}\text { Reference } \\
{[32]}\end{array}$} \\
\hline & & & & & 73 & 45.63 & & & \\
\hline & Controls & 160 & 34 & 21.25 & 82 & 51.25 & 44 & 27.5 & \\
\hline \multirow[t]{2}{*}{ Slovenia } & Type 2 diabetes & 399 & 67 & 16.8 & 189 & 47.4 & 143 & 35.8 & [30] \\
\hline & Controls & 196 & 26 & 13.3 & 91 & 46.4 & 79 & 40.3 & \\
\hline \multirow[t]{2}{*}{ Taiwan } & Ischemic stroke & 815 & 52 & 6.4 & 262 & 32.1 & 501 & 61.5 & [33] \\
\hline & Controls & 430 & 17 & 4 & 146 & 34 & 267 & 62 & \\
\hline \multirow[t]{2}{*}{ Chile } & Hypercholesterolemia & 116 & 25 & 21.6 & 78 & 67.2 & 13 & 11.2 & [34] \\
\hline & Controls & NA & NA & & NA & & NA & & \\
\hline \multirow[t]{2}{*}{ China } & Blood pressure & 608 & 297 & 48.8 & 237 & 39 & 74 & 12.2 & [35] \\
\hline & Controls & 616 & 348 & 56.5 & 216 & 35.1 & 52 & 8.4 & \\
\hline \multirow[t]{2}{*}{$\begin{array}{l}\text { Present } \\
\text { study }\end{array}$} & CAD & 200 & 54 & 27 & 124 & 62 & 22 & 11 & \\
\hline & Controls & 200 & 30 & 15 & 152 & 76 & 18 & 9 & \\
\hline Country & Disease & $n$ & $\begin{array}{l}\text { Homozygous } \\
\text { Wild Type }\end{array}$ & $\%$ & Hetero & us\% & $\begin{array}{l}\text { Homozygous } \\
\text { Mutant }\end{array}$ & $\%$ & Reference \\
\hline \multicolumn{10}{|l|}{ rs1529729 } \\
\hline \multirow[t]{2}{*}{ Iran } & CAD & 170 & 43 & 25.44 & 103 & 60.36 & 24 & 14.2 & [36] \\
\hline & Controls & 104 & 29 & 28.43 & 44 & 42.16 & 31 & 29.41 & \\
\hline \multirow[t]{2}{*}{ Sweden } & Cardiovascular & 5084 & 1610 & 31.7 & 2481 & 48.8 & 993 & 19.5 & [28] \\
\hline & Controls & NA & NA & & NA & & NA & & \\
\hline Present & CAD cases & 200 & 18 & 9 & 154 & 77 & 28 & 14 & \\
\hline study & Controls & 200 & 42 & 21 & 152 & 76 & 6 & 3 & \\
\hline
\end{tabular}

\section{Conclusions}

Taken together, the results of the present study indicated that the CT and TT genotypes of the rs1529729 polymorphism and the GA genotype of the rs5925 polymorphism are associated with decreased susceptibility to CAD in a South Indian population. However, these results must await further validation in future studies with larger sample sizes and in different populations. Moreover, a proteomic study on the effect of the rs1529729 and rs5925 polymorphisms on the LDLR protein is recommended.

Author Contributions: Conceptualization, all authors; Methodology, C.K.J., R.M. and I.E.; sample collection, C.K.J. and S.B.; Investigation C.K.J., R.M., and S.B. Analyses, C.K.J., R.M. and I.E.; Validation, R.M. and S.M.S.C.; Supervision, S.M.S.C.; Visualization, all authors; Original draft preparation C.K.J.; Writing-Review and Editing I.E. and R.M.

Funding: C.K.J was funded by a scholarship from UGC.

Acknowledgments: We thank the patients and the healthy control for their participation in this project.

Conflicts of Interest: The authors declare no conflict of interest.

\section{References}

1. De Rosa, S.; Arcidiacono, B.; Chiefari, E.; Brunetti, A.; Indolfi, C.; Foti, D.P. Type 2 Diabetes Mellitus and Cardiovascular Disease: Genetic and Epigenetic Links. Front. Endocrinol. (Lausanne) 2018, 9, 2. [CrossRef] [PubMed]

2. Fioranelli, M.; Bottaccioli, A.G.; Bottaccioli, F.; Bianchi, M.; Rovesti, M.; Roccia, M.G. Stress and Inflammation in Coronary Artery Disease: A Review Psychoneuroendocrineimmunology-Based. Front. Immunol. 2018, 9 , 2031. [CrossRef] [PubMed]

3. Lusis, A.J. Genetics of atherosclerosis. Trends Genet. 2012, 28, 267-275. [CrossRef] [PubMed]

4. Manduteanu, I.; Simionescu, M. Inflammation in atherosclerosis: A cause or a result of vascular disorders? J. Cell. Mol. Med. 2012, 16, 1978-1990. [CrossRef] [PubMed] 
5. Tousoulis, D.; Oikonomou, E.; Economou, E.K.; Crea, F.; Kaski, J.C. Inflammatory cytokines in atherosclerosis: Current therapeutic approaches. Eur. Heart J. 2016, 37, 1723-1732. [CrossRef] [PubMed]

6. Van De Sluis, B.; Wijers, M.; Herz, J. News on the molecular regulation and function of hepatic low-density lipoprotein receptor and LDLR-related protein 1. Curr. Opin. Lipidol. 2017, 28, 241-247. [CrossRef]

7. Abisambra, J.F.; Fiorelli, T.; Padmanabhan, J.; Neame, P.; Wefes, I.; Potter, H. LDLR expression and localization are altered in mouse and human cell culture models of Alzheimer's disease. PLoS ONE 2010, 5, e8556. [CrossRef]

8. Zhang, Y.; Ma, K.L.; Ruan, X.Z.; Liu, B.C. Dysregulation of the Low-Density Lipoprotein Receptor Pathway Is Involved in Lipid Disorder-Mediated Organ Injury. Int. J. Biol. Sci. 2016, 12, 569-579. [CrossRef]

9. Nikolic, J.; Belot, L.; Raux, H.; Legrand, P.; Gaudin, Y.; Albertini, A.A. Structural basis for the recognition of LDL-receptor family members by VSV glycoprotein. Nat. Commun. 2018, 9, 1029. [CrossRef]

10. Litvinov, D.Y.; Savushkin, E.V.; Dergunov, A.D. Intracellular and Plasma Membrane Events in Cholesterol Transport and Homeostasis. J. Lipids 2018, 2018, 22. [CrossRef]

11. Elfaki, I.; Almutairi, F.M.; Mir, R.; Khan, R.; Abu-Duhier, F. Cytochrome P450 CYP1B1*2 gene and its Association with T2D in Tabuk Population, Northwestern Region of Saudi Arabia. Asian J. Pharm. Clin. Res. 2018, 11, 55-59. [CrossRef]

12. Dadaev, T.; Saunders, E.J.; Newcombe, P.J.; Anokian, E.; Leongamornlert, D.A.; Brook, M.N.; Cieza-Borrella, C.; Mijuskovic, M.; Wakerell, S.; Al Olama, A.A.; et al. Fine-mapping of prostate cancer susceptibility loci in a large meta-analysis identifies candidate causal variants. Nat. Commun. 2018, 9, 2256. [CrossRef]

13. Almutairi, F.M.; Mir, R.; Abu-Duhier, F.; Khan, R.; Harby, K.; Elfaki, I. SLC2A2 Gene (Glucose Transporter 2) Variation is Associated with an Increased Risk of Developing T2d in an Ethnic Population of Saudi Arabia. Indian J. Public Health Res. Dev. 2019, 10, 600-605. [CrossRef]

14. Van der Harst, P.; Verweij, N. Identification of 64 Novel Genetic Loci Provides an Expanded View on the Genetic Architecture of Coronary Artery Disease. Circ. Res. 2018, 122, 433-443. [CrossRef] [PubMed]

15. Mir, R.; Jha, C.K.; Elfaki, I.; Rehman, S.; Javid, J.; Khullar, N.; Banu, S.; Chahal, S.M.S. MicroRNA-224 ( $r$ 188519172 A>G) gene variability is associated with a decreased susceptibility to Coronary Artery Disease: A Case-Control Study. Microrna 2018, 8, 198-205. [CrossRef] [PubMed]

16. Jha, C.K.; Mir, R.; Elfaki, I.; Khullar, N.; Rehman, S.; Javid, J.; Banu, S.; Chahal, S.M.S. Potential impact of microRNA-423 gene variability in coronary artery disease. Endocr. Metab. Immune Disord. Drug Targets 2018, 19, 67-74. [CrossRef] [PubMed]

17. Mir, R.; Jha, C.K.; Elfaki, I.; Javid, J.; Rehman, S.; Khullar, N.; Banu, S.; Chahal, S.M.S. Incidence of MicroR-4513C/T Gene Variability in Coronary Artery Disease- A case-Control Study. Endocr. Metab. Immune Disord. Drug Targets 2019. [CrossRef] [PubMed]

18. Jha, C.K.; Mir, R.; Khullar, N.; Banu, S.; Chahal, S.M.S. LDLR rs688 TT Genotype and T Allele Are Associated with Increased Susceptibility to Coronary Artery Disease-A Case-Control Study. J. Cardiovasc. Dev. Dis. 2018, 5, 31. [CrossRef]

19. Jha, C.K.; Mir, R.; Elfaki, I.; Javid, J.; Babakr, A.T.; Banu, S.; Chahal, S.M.S. Evaluation of the Association of Omentin 1 rs2274907 A>T and rs2274908 G<A Gene Polymorphisms with Coronary Artery Disease in Indian Population: A Case Control Study. J. Pers. Med. 2019, 9, 30.

20. Strisciuglio, T.; Franco, D.; Di Gioia, G.; De Biase, C.; Morisco, C.; Trimarco, B.; Barbato, E. Impact of genetic polymorphisms on platelet function and response to anti platelet drugs. Cardiovasc. Diagn. Ther. 2018, 8, 610-620. [CrossRef]

21. Elfaki, I.; Mir, R.; Almutairi, F.M.; Duhier, F.M.A. Cytochrome P450: Polymorphisms and Roles in Cancer, Diabetes and Atherosclerosis. Asian Pac. J. Cancer Prev. 2018, 19, 2057-2070. [PubMed]

22. Galasso, G.; Santulli, G.; Piscione, F.; De Rosa, R.; Trimarco, V.; Piccolo, R.; Cassese, S.; Iaccarino, G.; Trimarco, B.; Chiariello, M. The GPIIIA PlA2 polymorphism is associated with an increased risk of cardiovascular adverse events. BMC Cardiovasc. Disord. 2010, 10, 41. [CrossRef] [PubMed]

23. Strom, T.B.; Tveten, K.; Laerdahl, J.K.; Leren, T.P. Mutation G805R in the transmembrane domain of the LDL receptor gene causes familial hypercholesterolemia by inducing ectodomain cleavage of the LDL receptor in the endoplasmic reticulum. FEBS Open Biol. 2014, 4, 321-327. [CrossRef] [PubMed]

24. Jha, C.K.; Chahal, S.M.S.; Khullar, N.; Banu, S.; Mir, R. High-Quality Genomic DNA Extraction From Long Term Stored (LTS) Whole Blood Samples Using Glass Bead Method. Int. J. Health Sci. Res. 2016, 6, 288-292. 
25. Benjamin, E.J.; Blaha, M.J.; Chiuve, S.E.; Cushman, M.; Das, S.R.; Deo, R.; de Ferranti, S.D.; Floyd, J.; Fornage, M.; Gillespie, C.; et al. Heart Disease and Stroke Statistics-2017 Update: A Report From the American Heart Association. Circulation 2017, 135, e146-e603. [CrossRef] [PubMed]

26. Prabhakaran, D.; Jeemon, P.; Roy, A. Cardiovascular Diseases in India: Current Epidemiology and Future Directions. Circulation 2016, 133, 1605-1620. [CrossRef] [PubMed]

27. Wong, B.; Kruse, G.; Kutikova, L.; Ray, K.K.; Mata, P.; Bruckert, E. Cardiovascular Disease Risk Associated With Familial Hypercholesterolemia: A Systematic Review of the Literature. Clin. Ther. 2016, 38, 1696-1709. [CrossRef] [PubMed]

28. Kathiresan, S.; Melander, O.; Anevski, D.; Guiducci, C.; Burtt, N.P.; Roos, C.; Hirschhorn, J.N.; Berglund, G.; Hedblad, B.; Groop, L.; et al. Polymorphisms associated with cholesterol and risk of cardiovascular events. N. Engl. J. Med. 2008, 358, 1240-1249. [CrossRef] [PubMed]

29. Lee, J.D.; Hsiao, K.M.; Wang, T.C.; Lee, T.H.; Kuo, Y.W.; Huang, Y.C.; Hsu, H.L.; Lin, Y.H.; Wu, C.Y.; Huang, Y.C.; et al. Mutual effect of rs688 and rs5925 in regulating low-density lipoprotein receptor splicing. DNA Cell Biol. 2014, 33, 869-875. [CrossRef] [PubMed]

30. Nikolajević-Starčević, J.; Popović, D.; Letonja, M.Š.; Makuc, J.; Šeruga, M.; Vujkovac, A.C.; Pražnikar, Z.J.; Stare, J.; Petrovič, D. Polymorphism AvaII of the LDL receptor (rs5925) is associated with carotid-intima media thickness in patients with diabetes mellitus type 2. Slov. Med. J. 2014, 83, 5-12.

31. Al-Khateeb, A.; Zahri, M.K.; Mohamed, M.S.; Sasongko, T.H.; Ibrahim, S.; Yusof, Z.; Zilfalil, B.A. Analysis of sequence variations in low-density lipoprotein receptor gene among Malaysian patients with familial hypercholesterolemia. BMC Med. Genet. 2011, 12, 40. [CrossRef] [PubMed]

32. Rios-Gonzalez, B.E.; Ibarra-Cortes, B.; Ramirez-Lopez, G.; Sanchez-Corona, J.; Magana-Torres, M.T. Association of polymorphisms of genes involved in lipid metabolism with blood pressure and lipid values in mexican hypertensive individuals. Dis. Markers 2014, 2014, 9. [CrossRef] [PubMed]

33. Lee, J.D.; Lee, T.H.; Kuo, Y.W.; Huang, Y.C.; Hsu, H.L.; Lin, Y.H.; Wu, C.Y.; Huang, Y.C.; Lee, M.; Hsiao, K.M. Polymorphisms at the LDLR locus may be associated with ischemic cerebrovascular disease independent of lipid profile. Curr. Neurovasc. Res. 2012, 9, 200-206. [CrossRef] [PubMed]

34. Lagos, J.; Zambrano, T.; Rosales, A.; Salazar, L.A. APOE polymorphisms contribute to reduced atorvastatin response in Chilean Amerindian subjects. Int. J. Mol. Sci. 2015, 16, 7890-7899. [CrossRef] [PubMed]

35. Yin, R.X.; Aung, L.H.; Long, X.J.; Yan, T.T.; Cao, X.L.; Huang, F.; Wu, J.Z.; Yang, D.Z.; Lin, W.X.; Pan, S.L. Interactions of several genetic polymorphisms and alcohol consumption on blood pressure levels. Biofactors 2015, 41, 339-351. [CrossRef]

36. Jamaldini, S.H.; Babanejad, M.; Mozaffari, R.; Nikzat, N.; Jalalvand, K.; Badiei, A.; Sanati, H.; Shakerian, F.; Afshari, M.; Kahrizi, K.; et al. Association of polymorphisms at LDLR locus with coronary artery disease independently from lipid profile. Acta. Med. Iran. 2014, 52, 352-359. [PubMed] 